\title{
ENDOCRINOLOGY IN PREGNANCY
}

\section{Metabolic impact of bile acids in gestation}

\author{
Hei Man Fan, Alice L Mitchell and Catherine Williamson \\ Department of Women and Children's Health, School of Life Course Sciences, King's College London, London, UK
}

Correspondence should be addressed to C Williamson Email

catherine.williamson@kcl.ac. uk

\begin{abstract}
Bile acids are lipid-solubilising molecules that also regulate metabolic processes. Farnesoid X receptor (FXR) and Takeda G-protein coupled receptor 5 (TGR5) are two bile acid receptors with key metabolic roles. FXR regulates bile acid synthesis in the liver and influences bile acid uptake in the intestine. TGR5 is mainly involved in regulation of signalling pathways in response to bile acid uptake in the gut and therefore prandial response. Both FXR and TGR5 have potential as therapeutic targets for disorders of glucose and/or lipid homeostasis. Gestation is also known to cause small increases in bile acid concentrations, but physiological hypercholanaemia of pregnancy is usually not sufficient to cause any clinically relevant effects. This review focuses on how gestation alters bile acid homeostasis, which can become pathological if the elevation of maternal serum bile acids is more marked than physiological hypercholanaemia, and on the influence of FXR and TGR5 function in pregnancy on glucose and lipid metabolism. This will be discussed with reference to two gestational disorders: intrahepatic cholestasis of pregnancy (ICP), a disease where bile acids are pathologically elevated, and gestational diabetes mellitus (GDM), characterised by hyperglycaemia during pregnancy.
\end{abstract}

\section{Introduction}

Bile acids are a group of cholesterol-derived steroids with an aliphatic side chain that are synthesised in the liver and exported into the bile. Before secretion, bile acids are conjugated with either glycine or taurine, increasing hydrophilicity and reducing cytotoxicity (1). The primary functions of bile acids are to solubilise lipids by forming micelles to aid emulsification and facilitate absorption of fat by the gut (2), however, recent research

\section{Invited Author's profile}

Catherine Williamson is Professor of Women's Health at Kings College London and Honorary Consultant in Obstetric Medicine at Guy's and St Thomas' NHS Trust. She is a Fellow of the Academy of Medical Sciences and an NIHR Senior Investigator. Her principal research focus is on the endocrine signals that influence alterations in bile acid, lipid and glucose homeostasis in normal and pathological gestation. She also studies the maternal and fetus aetiology and outcomes of intrahepatic cholestasis of pregnancy (ICP) and gestational diabetes mellitus (GDM). She has

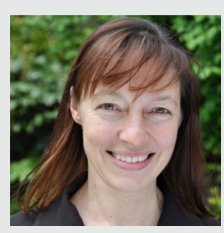
led prospective national cohort studies of rare gestational disorders, including severe ICP, hyperemesis gravidarum, cirrhosis and endocrine tumours in pregnancy. She is lead investigator of clinical trials of treatments for ICP and GDM with the aim of improving short and long -term outcomes for affected women and their children.

https://eje.bioscientifica.com https://doi.org/10.1530/EJE-20-1101
(C) 2021 European Society of Endocrinology Printed in Great Britain
Published by Bioscientifica Ltd. 
has demonstrated that bile acids also have hormonal and metabolic functions, particularly in glucose and lipid regulation. Bile acid signalling through the receptors farnesoid X receptor (FXR) and Takeda G-protein coupled receptor 5 (TGR5) (3) occurs in numerous cell types throughout the body to propagate metabolic processes.

Pregnancy is associated with a number of metabolic adaptations to facilitate fetal growth. There is a gradual increase in serum bile acids as gestation progresses, although for most women this remains within the normal reference range (4). However, for a small number of women, serum bile acids are elevated beyond this level, leading to intrahepatic cholestasis of pregnancy (ICP) which is associated with an increased risk of adverse pregnancy outcomes, including preterm birth, prolonged neonatal unit admission and stillbirth (4). Women with ICP also have an increased risk of developing gestational diabetes mellitus (GDM) (5), which is characterised by elevated plasma glucose levels and increased insulin resistance. Women with ICP have elevated serum triglyceride and LDL-cholesterol concentrations (6), similar to GDM, and it is thought bile acids and their receptors may also play a role in the development of impaired glucose tolerance in pregnancy.

In this review, bile acids and their receptors, FXR and TGR5, will be discussed in the context of regulation of glucose and lipid metabolism, human diseases, and recent research into their therapeutic potential. Focus will be on the gestational diseases ICP and GDM and the role bile acids play in their pathophysiology.

\section{Bile acid homeostasis}

Bile components, including bile salts, are synthesised in the liver, exported into bile ducts and stored in the gallbladder until meal ingestion. High concentrations of bile acids are toxic and therefore production and excretion are tightly regulated. There are two main pathways for bile acid synthesis: the classical and alternative pathway.

In humans, the classical bile acid synthesis pathway results in the conversion of cholesterol into the primary bile acids cholic acid (CA) and chenodeoxycholic acid (CDCA), and accounts for approximately $90 \%$ of bile acid synthesis. This hepatic-specific pathway involves at least 17 separate steps, and activity of the ratelimiting enzyme cholesterol $7 \alpha$-hydroxylase (CYP7A1) determines the size of the bile acid pool (7), while sterol $12 \alpha$-hydroxylase (CYP8B1) increases CA synthesis and the CA:CDCA ratio (7). The alternative bile acid synthesis pathway starts with hydroxylation of cholesterol by sterol 27-hydroxylase (CYP27A1) in extrahepatic sites to form 27-hydroxylcholesterol, which is then taken up by the liver and the majority converted to CDCA (3). Bile salts are formed by conjugation of bile acids with either taurine or glycine at a ratio of approximately 1:3 (7), and transported into the bile canaliculi through the bile salt export pump (BSEP; ABCB11) (8). Other membraneresiding transporters that influence bile components include multidrug resistance protein (MDR3; $A B C B 4$ ), a phosphatidylcholine (PC) floppase that transports $\mathrm{PC}$ from the inner to the outer canalicular membrane (and into the bile), and ATP-binding cassette transporters G5/G8 heterodimer (ABCG5/8), which transport cholesterol into the bile canaliculi $(9,10)$. From here, bile is transported to the gallbladder for storage. Figure 1 summarises the role of these hepatic pathways within the enterohepatic circulation of bile acids.

Ingestion of food stimulates release of bile from the gallbladder which facilitates the digestion and absorption of lipids and lipid-soluble vitamins. The gut microbiota in the ileum and colon deconjugate the primary bile acids, and further modify them through 7-dehydroxylation to produce secondary bile acids; lithocholic acid (LCA) is formed from CDCA whereas deoxycholic acid (DCA) is derived from CA (Fig. 2). The gut microbiota can further modify bile acids by $7 \alpha / \beta$-epimerisation to make ursodeoxycholic acid (UDCA), and more rarely by $3 \alpha / \beta$ epimerisation, $5 \alpha / \beta$-epimerisation or oxidation to produce iso-, allo-, or oxo-bile acids, respectively (11). The bile acid pool in the terminal ileum comprises approximately 30\% CA, 40\% CDCA, 20-30\% DCA and below 5\% LCA (1), although this varies between individuals as it is influenced by factors including nutrient availability and gut microbiota composition. Approximately $95 \%$ of the bile salts are reabsorbed, either through the apical sodiumdependent bile acid transporter (ASBT) at the distal ileum and colon, or through passive absorption of deconjugated or protonated uncharged conjugated bile acids along the length of the intestine (12). The remaining 5\% is excreted in the faeces, and this loss is compensated by approximately $500 \mathrm{mg} /$ day de novo bile acid synthesis (1). Reabsorbed bile acids are exported from ileal enterocytes into the enterohepatic circulation by the heterodimeric organic solute transporter $\alpha / \beta$ (OST $\alpha / \beta)$ on the basolateral membrane of the cells (1). The bile acids are transported via the portal vein back to the hepatocytes through the sodium taurocholate co-transporting polypeptide (NTCP) or organic anion transporting polypeptides (OATP) (1), reconjugated, and again exported into the bile duct (Fig. 1). 


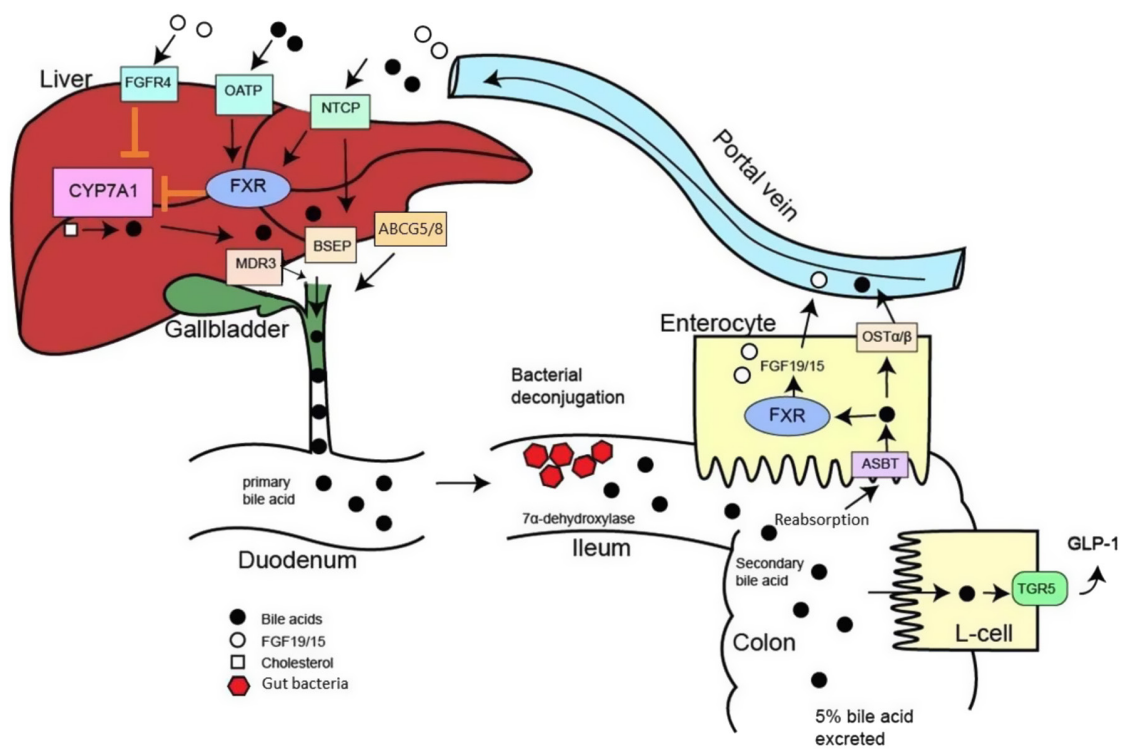

\section{Figure 1}

Enterohepatic circulation of bile acids schematic detailing the formation and export of bile acids into the intestinal tract. Bile acids are modified from primary to secondary forms by and deconjugation and $7 \alpha$-dehydroxylase produced by gut bacteria. The majority of bile acids are reabsorbed through enterocytes (approximately 95\%), with the remainder $(\sim 5 \%)$ excreted in the faeces. Reabsorbed bile acids in the L-cells activate TGR5 on the basolateral side which potentiates GLP-1 release. The reabsorbed bile acids are transported back to the liver via the portal vein, completing the enterohepatic cycle. FXR, Farenesoid X receptor; TGR5, Takeda G-protein coupled receptor 5; GLP1, glucagon-like peptide-1; ASBT, apical sodium-dependent bile acid transporter; OST $\alpha / \beta$, organic solute transporter $\alpha / \beta$; NTCP, taurocholate co-transporting polypeptide; OATP, organic anion transporting polypeptides; FGFR4, fibroblast growth factor receptor 4; CYP7A1, cholesterol 7 $\alpha$-hydroxylase; MDR3, multidrug resistance protein; BSEP, bile salt export pump; ABCG5/8, ATPbinding cassette transporters G5/G8 heterodimer; FGF19/15, fibroblast growth factor 19/15.

The role of bile acid receptors in glucose and lipid homeostasis

Daily synthesis of bile acids regulates the plasma cholesterol concentration, thereby ensuring this does not become too high. Catabolism of cholesterol to bile acids is regulated by CYP7A1 expression; high CYP7A1 expression leads to depletion of hepatic cholesterol and increased hepatic LDL receptor expression to replace the lost cholesterol by harvesting the circulatory cholesterol (13). The bile acid pool and composition are different in diabetic states, and there is evidence that the pool could increase in type 2 diabetes (T2DM). These changes could increase insulin resistance, affecting glucose metabolism and progress the pathogenesis of diabetes (2). Bile acid activation of FXR and TGR5 is well documented and both receptors have roles in bile acid, lipid and glucose metabolism. Understanding bile acid activation of FXR and TGR5 may provide key insights into the pathogenesis of metabolic disease states.

\section{FXR}

FXR is a nuclear receptor expressed mainly in the liver, intestine and kidneys, and is essential to regulating the metabolism and synthesis of bile acids. The primary bile acid CDCA is the most potent FXR ligand (CDCA $>$ LCA $>$ DCA $>$ CA; Fig. 3) (13). Hepatic FXR activation promotes transcription of small heterodimer protein (SHP), which represses transcription of CYP7A1, thereby reducing hepatic synthesis of bile acids (1) (Fig. 1). FXR also upregulates the expression of MDR3 and BSEP, promoting efflux of bile acids to further prevent bile acid build-up within hepatocytes. Intestinal FXR activation, via transintestinal bile acid flux, induces the 


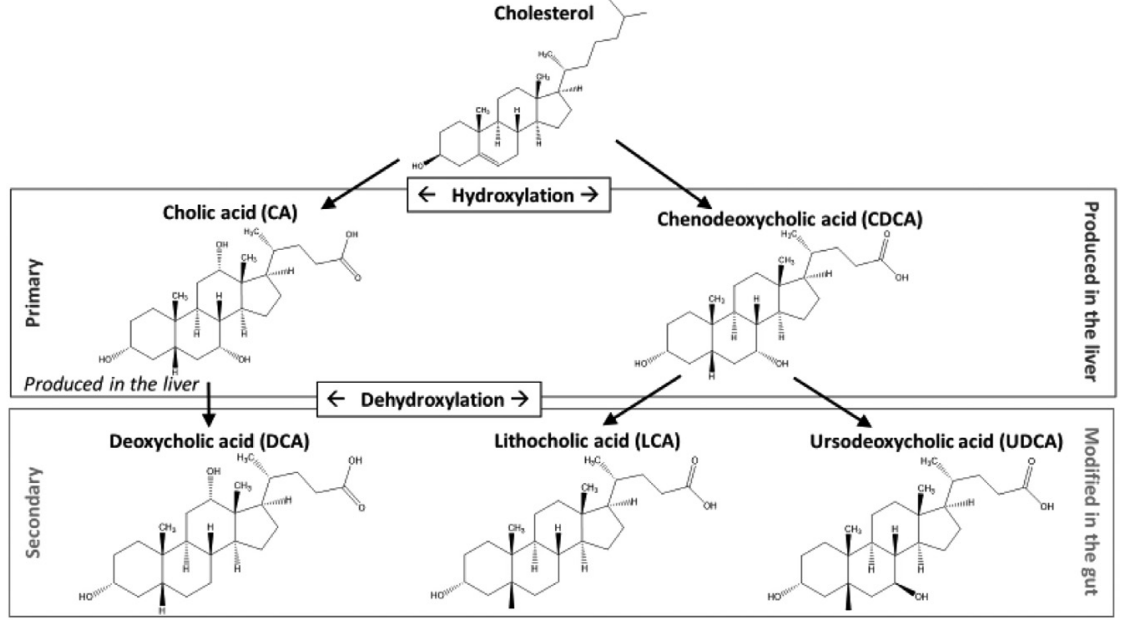

\section{Figure 2}

Bile acid structures pathways displaying the formation and structures of primary and secondary bile acids in their unconjugated form, derived from cholesterol. expression of fibroblast growth factor 19 (FGF19/FGF15 in mice) which is secreted by the intestinal epithelial cells. FGF19 is transported in the portal vein and binds hepatocyte fibroblast growth factor receptor 4 (FGFR4)/ beta-Klotho to cause repression of CYP7A1 transcription, further downregulating bile acid synthesis (2) (Fig. 1).

\section{FXR influences lipid and glucose metabolism}

Through transcriptional regulation, FXR activation also stimulates $\beta$-oxidation of fatty acids and decreases lipid levels in the serum and liver (14). Activation of hepatic FXR with agonists in diabetic/obese mice or rats fed a high-fat diet reduced serum and liver triglycerides and lipids. Hepatic expression of genes involving fatty acid synthesis, lipogenesis and gluconeogenesis were also reduced $(15,16)$. This demonstrates the importance of FXR in lipid metabolism and that FXR agonists have the potential to improve metabolic abnormalities.
Studies have also shown that activation of FXR has a beneficial effect on glucose metabolism, with FXR agonistic treatment or FXR overexpression lowering blood glucose levels in diabetic mice (17). Pathak and colleagues demonstrated that FXR agonists improve glycaemia and reduce diet-induced weight gain in mice (18), and another study demonstrated that bile acid activation of FXR in mice repressed gluconeogenic gene expression (19). Through FXR activation, mice fed a CA diet had reduced expression of phosphenolpyruvate carboxykinase, the rate-limiting enzyme in gluconeogenesis (20). FXR-null mice develop elevated serum free fatty acids, alongside impaired glucose and insulin tolerance, and elevated serum glucose levels. Activation of FXR with agonists in WT mice decreased serum glucose $(17,19)$. Other studies, however, have shown beneficial effects of inhibition or deletion of $\operatorname{FXR}(21,22)$. Mice with intestine-specific FXR knockout had improved oral glucose tolerance and lower body weight $(21,23)$. These contradictions could be explained by the differential effects of FXR activation in the liver vs the intestine.

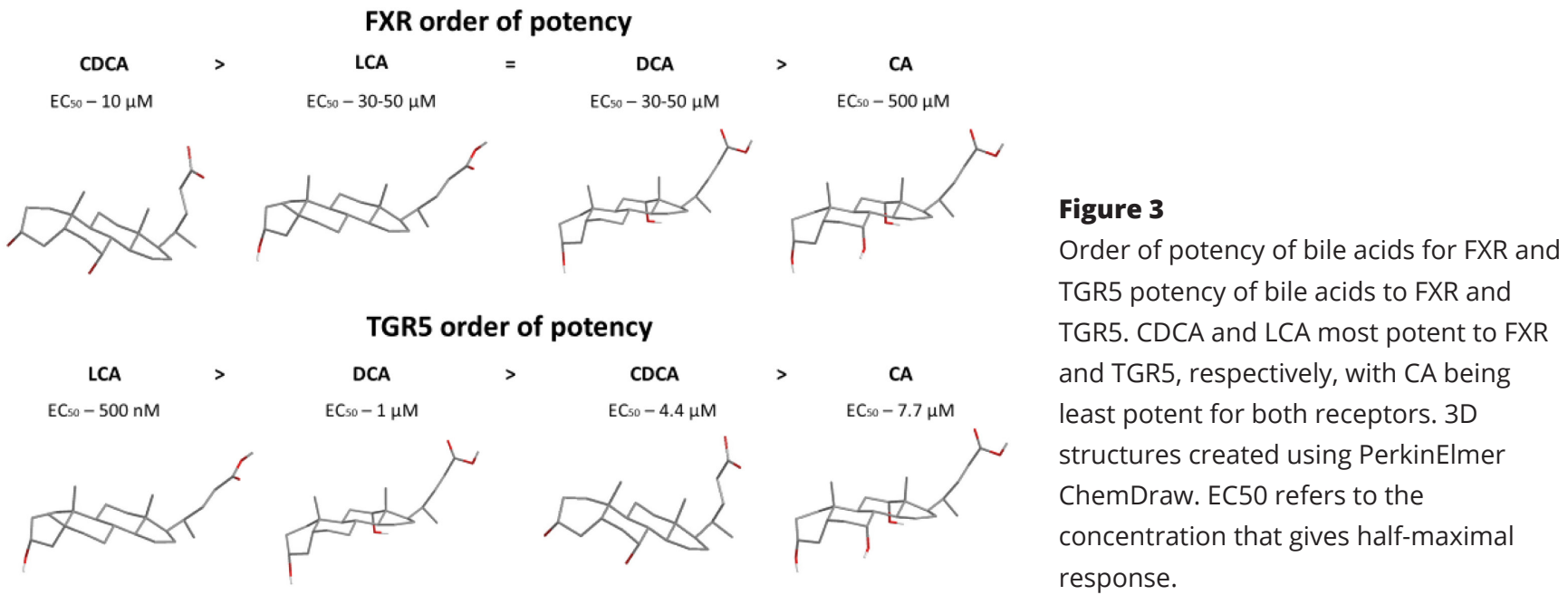

https://eje.bioscientifica.com 
It is also important to note that FXR expression is found in peripheral tissues including adipose tissue, islets of Langerhans and adrenal glands (24), and could contribute to glucose and lipid metabolism via actions in these tissues. In vivo and in vitro experiments involving animal islets demonstrated activation of FXR by bile acid stimulated insulin secretion $(25,26)$. In adipocytes, FXR appears to play a role in differentiation and promotes adipogenesis $(27,28)$.

\section{TGR5}

Bile acids also bind and activate TGR5, a cell surface G-protein-coupled receptor widely expressed in humans and animals. However, the most potent bile acid ligands for TGR5 differ to those that activate FXR (LCA > DCA >CDCA >CA; Fig. 3) (29). When activated, TGR5 stimulates adenylyl cyclase to increase concentrations of cyclic AMP, activating protein kinase A (PKA) and exerting cytosolic effects including calcium mobilisation and activating cellular signalling cascades such as nuclear factor $\kappa \mathrm{B}$, extracellular signal-regulated kinases and Akt/protein kinase B pathways $(30,31)$. Often, the signalling pathways of TGR5 are influenced by cell type and conditions. Most notable is its expression in the enteroendocrine $\mathrm{L}$ cells. TGR5 activation causes secretion of gut hormone glucagon-like-peptide 1 (GLP-1) in the small intestine and colon, which promotes insulin secretion $(18,32,33)$ (Fig. 1). Activation of TGR5 receptors at the pancreatic islets causes release of insulin and improves insulin sensitivity and glycaemic control $(34,35)$.

TGR5 activation also plays a role in lipid metabolism and energy expenditure. White and brown adipose tissue (WAT and BAT, respectively) are the two major adipose tissues in the body. WAT is adapted for storage of surplus fatty acids derived from the diet in the form of triglycerides and for subsequent release under conditions of negative energy balance in the body. WAT is also known to contribute to the inflammatory response that occurs in obesity $(36,37)$. In contrast, BAT is a highly vascularised, mitochondria-rich organ containing uncoupling protein 1 (UCP-1), which generates heat by uncoupling the mitochondrial proton gradient (38). TGR5 agonism causes remodelling of white adipocytes to give a more brown adipocyte-like phenotype, thus increasing $\beta$-oxidation and energy expenditure $(39,40)$. Improved glucose metabolism and energy consumption are induced by the cAMP/PKA pathway in TGR5-activated skeletal muscle, alongside promoting muscle cell differentiation and hypertrophy to increase muscle strength and function $(41,42)$. TGR5 expression is also found in several immune cells such as monocytes, macrophages and Kupffer cells; its activation exerts anti-inflammatory activities, including inhibition of the production of proinflammatory cytokines and induction of differentiation of anti-inflammatory immune cells (31, 43, 44). Many metabolic diseases have an inflammatory component, including diabetes; thus, TGR5-mediated regulation of immune cell function warrants further investigation.

\section{Further bile acid receptors}

Other receptors have been reported to have affinity towards bile acids. The primary function of the pregnane $\mathrm{X}$ receptor (PXR) is to detect foreign substances and protects the body by promoting transcription of genes involved in removing and metabolising toxic substances. PXR is highly expressed in the liver and intestine, with the most potent bile acid ligand being LCA (45). Strong evidence exists for ligand-activated PXR playing a role in lipid and glucose metabolism, though there are contradictory outcomes. Whilst some studies have shown PXR activation mediates lipogenesis, suppresses $\beta$-oxidation and induces hyperglycaemia $(46,47)$, others have reported that PXR activation improves glucose homeostasis and insulin sensitivity (48). Species and gender-specific differences are thought to explain these variable results. However, research on metabolic regulation through bile acid bound PXR activation is limited, and further investigations may reveal new role for bile acids acting on PXR.

The vitamin D receptor (VDR), when bound to vitamin $\mathrm{D}$, mediates calcium and bone metabolism, innate and adaptive immune system and cardiovascular function. LCA, can agonise VDR in the lower intestine, particularly in the ileum (49). However, the physiological relevance of LCA modulation of VDR function remains unclear. Recent research has pointed towards the ability of LCA to provide an immune protective effect at the epithelium via VDR activation (50). VDR has also been reported to have a role in maintaining glycaemia. A recent in vitro study demonstrated that an LCA derivative, LCA propionate, protects pancreatic $\beta$-cells from dedifferentiation (51). It remains to be seen whether LCA can regulate glucose metabolism via VDR.

The liver $\mathrm{X}$ receptor (LXR) is a nuclear receptor which has two isoforms: $\operatorname{LXR} \alpha$, which is highly expressed in tissues with high metabolic activity, including the liver, small intestine and adipocytes, and LXR $\beta$, which 
is expressed ubiquitously (45). Unlike FXR, activation of LXR increases transcription and activity of CYP7A1, increasing bile acid formation and reverse cholesterol transport, thus decreasing plasma cholesterol levels (45). FXR and LXR activation thus finely tune lipid, glucose and bile acid metabolism (13). Though primary bile acids are not regarded as agonists for LXR, some minor secondary bile acids have agonistic properties, such as hyocholic acid (HCA) and hyodeoxycholic acid (HDCA) $(52,53)$. Both HCA and HDCA are found at low levels in the serum and the intestinal tract, which raises questions as to whether their activation of LXR is of physiological relevance.

Alongside TGR5, other G-protein coupled receptors have also been documented to be activated by bile acids. Bile acids are known to interact with the muscarinic receptors, $\mathrm{M}_{1}-\mathrm{M}_{5}(3)$. Muscarinic receptors are responsible for the physiological effects of acetylcholine, which acts as a neurotransmitter in the brain or neuromuscular junctions and also mediates the parasympathetic system (3). There is increasing evidence that positive allosteric modulation of $\mathrm{M}_{3}$ muscarinic receptors improves glucose homeostasis and promotes insulin release $(54,55)$, and mice lacking $\mathrm{M}_{3}$ in pancreatic $\beta$-cells displayed impaired glucose control and reduced insulin release, producing a diabetic phenotype (54).

Sphingosine-1 phosphate receptor subtype 2 (S1PR2), expressed in a variety of tissues, is another G-protein coupled receptor (3) for which bile acids are also ligands. When activated, S1PR2 mediates numerous cell functions including increasing cell permeability, promoting immune cell function, muscle contraction and neuron migration (56). Research into the role of S1PR2 in metabolic function has demonstrated that its activation lowers glucose levels and upregulates lipid metabolism $(56,57)$.

\section{Gestational changes in bile acid metabolism}

Serum bile acid concentrations are raised in pregnancy compared to non-pregnant adults, resulting in a mild gestational hypercholanaemia. The concentrations of CA and CDCA are also reported to change as gestation advances $(58,59,60,61,62)$. The composition of the maternal gut microbiome may provide some answers to these alterations, with some studies reporting a gradual reduction of Bacteroidetes and increase in Firmicutes as pregnancy progresses, similar to the changes in microbes reported in obesity $(63,64)$. In a separate study, advancing gestation was associated with enhanced microbial bile acid deconjugation (secondary to an increase in Baceroidetesencoded bile salt hydrolase), reduced ileal bile acid uptake and therefore lowered FXR induction in enterocytes (65), resulting in increased hepatic bile acid synthesis. Along with reduced ileal FXR activity, studies of pregnant mice showed reduced FGF15, and reduced expression of bile acid transporters late in gestation $(65,66)$. More detailed studies that take account of individual variation in gestational phenotypes are required to delineate the alterations in specific enterotypes with advancing gestation.

Pregnancy hormones have also been shown to influence bile acid homeostasis. Studies in mice demonstrated that, as serum bile acid levels increase during gestation, FXR expression is suppressed. This was associated with the downregulation of bile acid transporters such as BSEP, NTCP and OATP, particularly exemplified in the late stage of pregnancy $(67,68)$. Hormones such as progesterone and oestrogen, whose concentrations increase as gestation progresses, contribute to the changes in bile acid metabolism. Oestrogen and its metabolites inhibit FXR and BSEP, and increase CYP7A1 activity in animal studies $(67,69,70)$. Similarly, BSEP and NTCP are inhibited by sulphated progesterone metabolites, and whilst progesterone sulphates exert partial agonism towards FXR, this prevents bile acid binding and reduces overall activation of $\operatorname{FXR}(71,72,73)$. Therefore, both oestrogen, progesterone and their metabolites contribute to raised bile acids during normal pregnancy.

Metabolic changes also occur during pregnancy to accommodate the demands of the fetus. Serum lipids, particularly triglycerides, and LDL-cholesterol increase as pregnancy progresses $(74,75)$. Insulin resistance is typically seen in pregnancy, which contributes to the stimulation of fatty acid synthesis, and increased lipid release into the serum (76). Enhanced hepatic gluconeogenesis and impaired insulin sensitivity result in higher circulating glucose concentrations during the third trimester. Insulin resistance is normally compensated for by an increase in the size and number of pancreatic islets, thereby enhancing glucose-stimulated insulin secretion (GSIS) (77). High oestrogen levels during pregnancy stimulate hepatic lipogenesis and reduce clearance of circulating triglyceride-rich lipoproteins (76). Oestradiol acts on the $\beta$-cells to enhance GSIS, and is also believed to be involved in developing maternal insulin resistance and glucose intolerance $(78,79)$. One of the suggested mechanisms of action occurs by oestradiol binding directly to insulin and the insulin receptor to cause insulin resistance (80). Elevated levels of progesterone have also been implicated 
in contributing to decreased insulin sensitivity, increased insulin resistance and glucose intolerance (79). One mechanism through which this occurs is through inhibition of insulin-induced glucose transporter type 4 (GLUT4) translocation. Progesterone prevents GLUT4 translocation by suppressing the phosphoinositide 3-kinase-mediated pathway, inhibiting Akt phosphorylation and decreasing insulin-induced phosphorylation of $\mathrm{Cbl}$ signalling proteins, causing reduced cellular glucose uptake (81).

It is likely that TGR5 signalling is affected during pregnancy. Activation of TGR5 in enteroendocrine cells causes GLP-1 secretion. During normal pregnancy, fasting serum GLP-1 concentrations increase from the second to third trimester, which is thought to compensate for the increase in glycaemia and insulin resistance (82). With changes in the gut microbiome promoting enhanced hepatic bile acid synthesis, and also increased microbial deconjugation and dehydroxylation of primary bile acids to LCA and DCA, the TGR5 receptor would be further activated, thereby influencing maternal metabolism. GLP-1 secretion is key for pancreatic $\beta$-cell adaptations. During normal pregnancy, islet and $\beta$-cell area increase to compensate for changes in both mice and humans. In GLP-1 receptor null mice, these islet adaptations are abolished, suggesting that GLP- 1 is a key mediator in $\beta$-cell mass expansion and related adaptations in pregnancy (83).

Bile acid composition and concentration may also differ in gestational disease states compared to uncomplicated pregnancies, particularly in the metabolic disorders ICP and GDM.

\section{Bile acids in gestational disease}

\section{Intrahepatic cholestasis of pregnancy}

ICP is the most common pregnancy-specific liver disease. Women with ICP most commonly present in the third trimester with pruritus and elevated serum bile acids, which can occur alongside raised liver transaminases. ICP accounts for roughly $1 \%$ of pregnancies in Europe and North America, with higher incidence in women of South Asian and South American ancestry, occurring most commonly in Chile and neighbouring countries (4). As well as pruritus, hypercholanaemia and abnormal liver function, maternal features of ICP include impaired glucose tolerance and dyslipidaemia (6). ICP is associated with an increased risk of adverse perinatal outcomes, including preterm birth, meconium stained amniotic fluid and stillbirth $(84,85,86)$. ICP has a complex aetiology with hormonal and genetic factors. Most women are diagnosed when the concentrations of both oestrogens and progesterone are at their highest in the later stages of pregnancy. Sulphated progesterone metabolites, implicated in the pathogenesis of ICP, are elevated in women with ICP in the third trimester, but are raised before the onset of pruritus (87). Genetic studies have demonstrated pathological variants in genes involved in bile acid synthesis and transport (particularly $A B C B 4$ and $A B C B 11)$ in ICP $(88,89)$.

As well as the total serum concentration, the bile acid profile is also altered. In normal pregnancy the CA/ CDCA ratio is increased, and this is further amplified in ICP by a larger increase in CA $(90,91)$. This ratio change increases the hydrophilicity of the bile acid pool, due to the extra hydroxyl group on CA. This further reduces FXR activation in ICP as CA is a less potent agonist of FXR (Fig. 3 ), but is likely to be less harmful than if other bile acids were elevated as CA should exhibit cytoprotection over the more cytotoxic hydrophobic bile acids (92). Activation of TGR5 by bile acids, or other agonists such as progesterone sulfates, may also play a role in the pruritus associated with ICP $(87,93,94)$. As well as maternal effects, bile acids have been directly implicated in fetal arrhythmias, with fetal PR interval elongation and abnormal calcium dynamics reported $(95,96,97,98)$. FXR function has also been linked to the pathophysiology of ICP. FXR function is reduced in pregnancy due to the rise in oestrogen and its metabolites, causing a cholestatic phenotype $(67,71)$. While reduced FXR function is likely to occur in all pregnancies, in some women gestational changes will exacerbate susceptibility to hypercholanaemia to cause ICP.

Ursodeoxycholic acid (UDCA) is a hydrophilic secondary bile acid, normally used to treat a variety of cholestatic liver disorders. UDCA lowers serum levels of bile acids, acting on BSEP, MDR3 and multidrug resistance-associated protein 4 , which improves biliary secretion of bile acids $(99,100)$. Other effects include protection of the liver from bile acid-induced apoptosis, anti-inflammatory actions and stabilisation of the 'biliary bicarbonate umbrella' (101). UDCA treatment also alters the bile acid pool, constituting approximately $60 \%$ of total bile acid measurements in treated women and replacing more harmful bile acids (102). UDCA is a commonly used treatment for ICP, with studies demonstrating reductions in maternal features of ICP, such as itch, hypercholanaemia, elevated transaminases and adverse outcomes $(103,104)$. However, a recent trial demonstrated that UDCA did not reduce the frequency of a composite endpoint that perinatal death, spontaneous and iatrogenic preterm birth and admission to the neonatal unit for more than $4 \mathrm{~h}$ 
(105). Ongoing research is evaluating whether UDCA may be of benefit to a subgroup of women with ICP, or only those at risk of specific adverse pregnancy outcomes.

\section{Gestational diabetes mellitus}

GDM is characterised by the pathological development of insulin resistance and hyperglycaemia during pregnancy, which resolves following delivery. Due to the lack of consensus and diagnostic standard for GDM worldwide, there is a large variation in the prevalence of GDM which makes it challenging to compare across countries and regions. Although pre-existing diseases such as obesity contribute to the likelihood of developing GDM, multiple risk factors are implicated in its pathogenesis, including age, ethnicity, family history of diabetes, smoking and genetic susceptibility (106). With many women choosing to have children at a later stage of their life and maternal obesity rates increasing worldwide every year (106), the prevalence has been rising, regardless of the diagnostic criteria. The pathophysiology of GDM is multifactorial. While the metabolic adaptations of normal pregnancy described above occur in all pregnancies, GDM occurs when the islets cannot meet the heightened insulin demand, and the $\beta$-cells become defective, resulting in hyperglycaemia (106). GDM typically occurs in the third trimester when insulin resistance is at its highest and peripheral insulin sensitivity at its lowest (106).

GDM is associated with both short- and long-term complications. Shorter-term consequences include accelerated fetal growth, macrosomia, neonatal hypoglycaemia, and jaundice (107, 108, 109). Longerterm complications include increased risk of developing T2DM in both the mother and offspring $(107,110,111$, 112), and an increased risk of developing metabolic syndrome, cardiovascular, kidney and liver diseases for the mother $(106,107)$. A recent study examining 11-12 year old offspring of women with GDM determined that these children were also at increased risk of hyperglycaemia, diabetes and obesity $(110,113)$.

Initial treatment for GDM involves a lifestyle modification immediately after diagnosis, including dietary modification and exercise (114). If hyperglycaemia is not resolved within 1-2 weeks, pharmacological treatment is initiated. Metformin and/or insulin are often given as first line treatments, with sulfonylureas sometimes given as an alternative, depending on different country guidelines (114). The metformin in gestational diabetes (MiG) trial demonstrated that mothers randomised to metformin, compared to insulin, had reduced maternal weight gain and gestational hypertension (115). However, the rate of large for gestational age (LGA) offspring was not affected and the children had more s.c. fat at 2 years of age after maternal metformin treatment (116). Furthermore, metformin use has been associated with greater childhood size, adiposity and inferior cardiometabolic health (117). These studies have raised concerns that metformin, currently used by many women with GDM, does not adequately prevent adverse perinatal outcomes, and may have negative long-term effects on the metabolic health of the children (118). However, a recent study has provided more reassuring data: the 3-5 year old children of obese women randomised to take metformin in pregnancy had lower gluteal and tricep circumferences, lower systolic blood pressure and improved left ventricular diastolic function compared to the children of obese women randomised to placebo (119). Thus, more research is required to establish whether maternal metformin treatment improves long-term cardiometabolic outcomes for exposed fetuses. Indeed, even insulin treatment (the 'gold-standard' pharmacological approach) was not shown to be of definitive benefit for GDM offspring in the most recent Cochrane review, and was thought to possibly increase the risk of raised blood pressure compared to oral treatments (120). The sulfonylurea, glibenclamide, has not been shown to be superior to insulin treatment in randomised trials (121), or as an add-on therapy to metformin (122). Sulfonylurea use is also linked with higher rates of LGA babies and neonatal hypoglycaemia compared with offspring of GDM women treated with insulin or metformin (123). Thus, while the recommended treatments should be prescribed for women with GDM, the potential long-term effects for the child should be taken into careful consideration, and there is a need for more effective intervention strategies to be developed, likely with consideration of individual risk factors as GDM is a heterogeneous disorder. However treatment for GDM does not seem to improve the longterm effects seen in children $(124,125)$, although current postpartum studies evaluating children born from GDM women are of relatively short duration.

\section{Impact of bile acids in ICP and GDM}

ICP and GDM have some similarities; both are gestational metabolic disorders associated with maternal dyslipidaemia. Although bile acids and their receptors have a greater impact on ICP, it is plausible that bile acid signalling also influences the risk of GDM, and 
modulation of bile acid pathways may be of benefit in both conditions.

There is an increasing research focus on the relationship between bile acids and the risk of T2DM, in particular the relevance of the CA:CDCA ratio and CYP8B1 function $(126,127)$. However, studies of bile acids in GDM are comparatively limited. As described earlier in this article, elevated serum bile acids and changes in the bile acid pool also occur in normal pregnancy and are heightened in ICP. Furthermore women with ICP have an increased risk of developing $\operatorname{GDM}(5,128,129)$. Total and individual bile acid species have been found to be higher in women with GDM in the third trimester (130). Elevated total bile acids were also found in women in their first trimester who went on to develop GDM $(131,132)$. However, other studies found a reduction in bile acids in GDM women recruited from the first and second trimester $(133,134)$. These differences could be due to ethnicity, the heterogeneous aetiology of GDM or variations in the method used to assay bile acids. The composition of the bile acid pools also differs between these studies, and some report alterations in the concentrations of minor bile acids that may not be of relevance to clinical metabolic phenotypes. This discrepancy between studies of bile acids in GDM warrants further investigation. It is important for future studies to use consistent measurement techniques in large cohorts of women with GDM, and to match the BMI in women with uncomplicated pregnancies, alongside ethnic group, gestational week of pregnancy and feeding/fasting blood sampling, as these factors all influence the concentration of specific bile acid species in the serum.

It is possible that changes in FXR and TGR5 activity could affect GDM susceptibility. Since both receptors play a role in regulation of glucose homeostasis, changes to normal receptor function are also likely to affect glucose metabolism. Consistent with this, mice deficient of FXR or TGR5 develop gestational impaired glucose tolerance, and $\mathrm{FXR}^{-/}$mice have insulin resistance in pregnancy (135). It is plausible both FXR and TGR5 could contribute to the pathophysiology of GDM and could be the link between the increased risk of developing GDM in ICP women.

\section{Bile acid receptors and therapeutics for gestational diseases}

Due to the increasing evidence of the involvement of FXR and TGR5 in energy metabolism, manipulation of these receptors could be key in improving metabolic disease such as diabetes. As a result of the cytotoxic nature of hydrophobic bile acids, concerns have been raised as to the safety of using bile acids as pharmaceuticals. To avoid this issue, much research has evaluated semi-synthetic analogues or synthetic TGR5 or FXR agonists as potential therapeutics for metabolic diseases. Studies on targeting FXR regulation of metabolism appear to be contradictory. The FXR agonist obeticholic acid (OCA) has delivered promising results in clinical trials for liver-based metabolic diseases and T2DM in non-pregnant adults, including improving insulin sensitivity (136). However, in mouse models of GDM, OCA did not produce the full effects seen in other studies; whilst treatment reduced plasma cholesterol, glucose tolerance was not improved (137). Research into FXR-specific therapeutics for gestational disorders such as ICP or GDM is also currently lacking. However, FXR agonism provides some benefits in mouse models of hypercholanaemia, with improved fetal bile acid profiles $(138,139)$.

Likewise, TGR5 agonism has been researched as a therapeutic for ameliorating symptoms of diabetes, with TGR5 agonists in diabetic mice improving glucose homeostasis (41). However, to date, no research has looked specifically at the impact of TGR5 receptor activation on biochemical features of GDM. Several novel TGR5 agonists exist and many show encouraging effects when used in animal models of diabetes (140, 141, 142, 143, 144, 145). One recent example used a novel, orally administered TGR5 agonist, RDX8940. This induced incretin secretion and improved insulin sensitivity with minimal side effects in western diet-fed mice (145). Another study which used another novel TGR5 agonist, WB403, on a model of T2DM mice improved glucose tolerance and decreased fasting blood glucose. WB403 administration caused changes at the islet level, increasing pancreatic $\beta$-cells in mice (143). Clinical trials using TGR5 selective agonists have also been carried out with promising results (146). Side effects are a major concern for novel TGR5 agonists due to TGR5 having broad multi-organ expression. However, using organ-restricted agonists would avoid these side effects and would consequently likely have acceptable safety profiles. Currently TGR5 agonists with low intestinal absorption rates have been designed that may have therapeutic value. Studies have shown their ability to cross cell membranes and that they show specificity for TGR5 receptors without contributing to systemic absorption $(147,148)$. Lasalle et al. 2017 designed a gut-restricted TGR5 agonist named compound 24 . When used in diet-induced obese and insulin resistant mice, sustained GLP-1 release and decreased fasted plasma insulin levels were observed with low systemic levels of compound 24 detected. Many of 
these agonists could have the potential in alleviating GDM symptoms, though further studies are required to explore the relationship between TGR5 and GDM.

Bile acids for the treatment of diabetes are currently being investigated. A recent study of UDCA treatment in people with T2DM and chronic liver disease resulted in weight loss and reduction of HbA1c over 12 weeks (149). Furthermore, a meta-analysis showed significant reductions in fasting plasma glucose, HbA1c and plasma insulin concentrations in UDCA treated people with nonalcoholic fatty liver disease (a disorder linked with T2DM and previous GDM) $(150,151)$. The improvements seen in UDCA treatment for T2DM could translate as a plausible treatment for those who have GDM and future studies could look to see if these improvements in T2DM could be replicated in GDM patients.

\section{Conclusions}

Bile acids are signalling molecules that influence energy metabolism. Emerging research is revealing that bile acids and their receptors contribute to modulation of bile acid, lipid and glucose metabolism and that they influence the pathophysiology of diseases, including the gestational disorders ICP and GDM. Research into FXR has expanded the knowledge of not only how the body maintains tight control of bile acid production and export but has revealed additional roles for this nuclear receptor in lipid and glucose metabolism. Conflicting studies exist detailing how FXR activation alters glucose homeostasis and further research is necessary to clarify its role in disorders of glucose homeostasis. On the other hand, TGR5 stimulation in the gut, and associated release of GLP-1, is likely to be valuable for modulating gestational diseases in which women display glucose intolerance. Due to TGR5 expression in numerous organs, organspecific TGR5 agonists could be an attractive option. While the relationship between ICP and bile acids is well established, the potential relationship between bile acids and susceptibility to GDM is currently less well understood. More detailed investigation of the impact of therapeutic targeting of bile acid receptors is likely to provide data to establish whether this will improve metabolic derangements in ICP and GDM, and therefore future maternal and child health.

\section{Declaration of interest}

The authors declare that there is no conflict of interest that could be perceived as prejudicing the impartiality of this review.
Funding

C W is supported by the NIHR senior investigator award.

\section{References}

1 Šarenac TM \& Mikov M. Bile acid synthesis: from nature to the chemical modification and synthesis and their applications as drugs and nutrients. Frontiers in Pharmacology 20189 939. (https://doi. org/10.3389/fphar.2018.00939)

2 Ahmad TR \& Haeusler RA. Bile acids in glucose metabolism and insulin signalling - mechanisms and research needs [Internet]. Nature Reviews: Endocrinology 201915 701-712. (https://doi.org/10.1038/ s41574-019-0266-7)

3 Kiriyama Y \& Nochi H. The biosynthesis, signaling, and neurological functions of bile acids. Biomolecules 20199232 . (https://doi. org/10.3390/biom9060232)

4 McIlvride S, Dixon PH \& Williamson C. Bile acids and gestation. Molecular Aspects of Medicine 201756 90-100. (https://doi. org/10.1016/j.mam.2017.05.003)

5 Martineau M, Raker C, Powrie R \& Williamson C. Intrahepatic cholestasis of pregnancy is associated with an increased risk of gestational diabetes. European Journal of Obstetrics, Gynecology, and Reproductive Biology 2014176 80-85. (https://doi.org/10.1016/j. ejogrb.2013.12.037)

6 Martineau MG, Raker C, Dixon PH, Chambers J, Machirori M, King NM, Hooks ML, Manoharan R, Chen K, Powrie R et al. The metabolic profile of intrahepatic cholestasis of pregnancy is associated with impaired glucose tolerance, dyslipidemia, and increased fetal growth. Diabetes Care 201538 243-248. (https://doi. org/10.2337/dc14-2143)

7 Chiang JYL \& Ferrell JM. Bile acid metabolism in liver pathobiology [Internet]. Gene Expression 201818 71-87. (https://doi.org/10.3727/1 05221618X15156018385515)

8 Kullak-Ublick GA, Stieger B, Hagenbuch B \& Meier PJ. Hepatic transport of bile salts [Internet]. Seminars in Liver Disease 200020 273-292. (https://doi.org/10.1055/s-2000-9426)

9 Graf GA, Yu L, Li WP, Gerard R, Tuma PL, Cohen JC \& Hobbs HH. ABCG5 and ABCG8 are obligate heterodimers for protein trafficking and biliary cholesterol excretion. Journal of Biological Chemistry 2003 278 48275-48282. (https://doi.org/10.1074/jbc.M310223200)

10 Oude Elferink RPJ \& Paulusma CC. Function and pathophysiological importance of ABCB4 (MDR3 P-glycoprotein) [Internet]. Pflugers Archiv 2007453 601-610. (https://doi.org/10.1007/s00424-006-00629)

11 Wahlström A, Sayin SI, Marschall HU \& Bäckhed F. Intestinal crosstalk between bile acids and microbiota and its impact on host metabolism. Cell Metabolism 201624 41-50. (https://doi. org/10.1016/j.cmet.2016.05.005)

12 Dawson PA \& Karpen SJ. Intestinal transport and metabolism of bile acids [Internet]. Journal of Lipid Research 201556 1085-1099. (https:// doi.org/10.1194/jlr.R054114)

13 Kalaany NY \& Mangelsdorf DJ. LXRS and FXR: the yin and yang of cholesterol and fat metabolism. Annual Review of Physiology 200668 159-191. (https://doi.org/10.1146/annurev. physiol.68.033104.152158)

14 Savkur RS, Bramlett KS, Michael LF \& Burris TP. Regulation of pyruvate dehydrogenase kinase expression by the farnesoid $\mathrm{X}$ receptor [Internet]. Biochemical and Biophysical Research Communications 2005329 391-396. (https://doi.org/10.1016/j. bbrc.2005.01.141)

15 Cipriani S, Mencarelli A, Palladino G \& Fiorucci S. FXR activation reverses insulin resistance and lipid abnormalities and protects against liver steatosis in Zucker (fa/fa) obese rats. Journal of Lipid Research 201051 771-784. (https://doi.org/10.1194/jlr.M001602) 
16 Liu Y, Song A, Yang X, Zhen Y, Chen W, Yang L, Wang C \& Ma H. Farnesoid $\mathrm{X}$ receptor agonist decreases lipid accumulation by promoting hepatic fatty acid oxidation in $\mathrm{db} / \mathrm{db}$ mice. International Journal of Molecular Medicine 201842 1723-1731. (https://doi. org/10.3892/ijmm.2018.3715)

17 Zhang Y, Lee FY, Barrera G, Lee H, Vales C, Gonzalez FJ, Willson TM \& Edwards PA. Activation of the nuclear FXR improves hyperglycemia and hyperlipidemia in diabetic mice. PNAS $2006 \mathbf{1 0 3}$ 1006-1011. (https://doi.org/10.1073/pnas.0506982103)

18 Pathak P, Xie C, Nichols RG, Ferrell JM, Boehme S, Krausz KW, Patterson AD, Gonzalez FJ \& Chiang JYL. Intestine farnesoid X receptor agonist and the gut microbiota activate G-protein bile acid receptor-1 signaling to improve metabolism. Hepatology 201868 1574-1588. (https://doi.org/10.1002/hep.29857)

19 Ma K, Saha PK, Chan L \& Moore DD. Farnesoid X receptor is essential for normal glucose homeostasis. Journal of Clinical Investigation 2006 116 1102-1109. (https://doi.org/10.1172/JCI25604)

20 De Fabiani E, Mitro N, Gilardi F, Caruso D, Galli G \& Crestani M. Coordinated control of cholesterol catabolism to bile acids and of gluconeogenesis via a novel mechanism of transcription regulation linked to the fasted-to-fed cycle. Journal of Biological Chemistry 2003 278 39124-39132. (https://doi.org/10.1074/jbc.M305079200)

21 Li F, Jiang C, Krausz KW, Li Y, Albert I, Hao H, Fabre KM, Mitchell JB, Patterson AD \& Gonzalez FJ. Microbiome remodelling leads to inhibition of intestinal farnesoid $\mathrm{X}$ receptor signalling and decreased obesity. Nature Communications 20134 2384. (https://doi. org/10.1038/ncomms3384)

22 Jiang C, Xie C, Lv Y, Li J, Krausz KW, Shi J, Brocker CN, Desai D, Amin SG, Bisson WH et al. Intestine-selective farnesoid X receptor inhibition improves obesity-related metabolic dysfunction. Nature Communications 20156 10166. (https://doi.org/10.1038/ ncomms10166)

23 Xie C, Jiang C, Shi J, Gao X, Sun D, Sun L, Wang T, Takahashi S, Anitha M, Krausz KW et al. An intestinal farnesoid X receptorceramide signaling axis modulates hepatic gluconeogenesis in mice. Diabetes 201766 613-626. (https://doi.org/10.2337/db16-0663)

24 Lefebvre P, Cariou B, Lien F, Kuipers F \& Staels B. Role of bile acids and bile acid receptors in metabolic regulation. Physiological Reviews 200989 147-191. (https://doi.org/10.1152/physrev.00010.2008)

25 Düfer M, Hörth K, Wagner R, Schittenhelm B, Prowald S, Wagner TFJ, Oberwinkler J, Lukowski R, Gonzalez FJ, Krippeit-Drews P et al. Bile acids acutely stimulate insulin secretion of mouse $\beta$-cells via farnesoid X receptor activation and K ATP channel inhibition. Diabetes 201261 1479-1489. (https://doi.org/10.2337/db11-0815)

26 Schittenhelm B, Wagner R, Kähny V, Peter A, Krippeit-Drews P, Düfer M \& Drews G. Role of FXR in $\beta$-cells of lean and obese mice. Endocrinology 2015156 1263-1271. (https://doi.org/10.1210/ en.2014-1751)

27 Rizzo G, Disante M, Mencarelli A, Renga B, Gioiello A, Pellicciari R $\&$ Fiorucci $\mathrm{S}$. The farnesoid $\mathrm{X}$ receptor promotes adipocyte differentiation and regulates adipose cell function in vivo. Molecular Pharmacology 200670 1164-1173. (https://doi.org/10.1124/ mol.106.023820)

28 Van Zutphen T, Stroeve JHM, Yang J, Bloks VW, Jurdzinski A, Roelofsen H, Huijkman NCA, van Dijk TH, Vonk RJ, van Deursen J et al. FXR overexpression alters adipose tissue architecture in mice and limits its storage capacity leading to metabolic derangements. Journal of Lipid Research 201960 1547-1561. (https://doi. org/10.1194/jlr.M094508)

29 Kawamata Y, Fujii R, Hosoya M, Harada M, Yoshida H, Miwa M, Fukusumi S, Habata Y, Itoh T, Shintani Y et al. A G protein-coupled receptor responsive to bile acids. Journal of Biological Chemistry 2003 278 9435-9440. (https://doi.org/10.1074/jbc.M209706200)

30 Guo C, Chen WD \& Wang YD. TGR5, not only a metabolic regulator [Internet]. Frontiers in Physiology 20167 646. (https://doi. org/10.3389/fphys.2016.00646)
31 Chávez-Talavera O, Tailleux A, Lefebvre P \& Staels B. Bile acid control of metabolism and inflammation in obesity, Type 2 diabetes, dyslipidemia, and nonalcoholic fatty liver disease. Gastroenterology 2017152 1679.e3-1694.e3. (https://doi.org/10.1053/j. gastro.2017.01.055)

32 Christiansen CB, Trammell SAJ, Albrechtsen NJW, Schoonjans K, Albrechtsen R, Gillum MP, Kuhre RE \& Holst JJ. Bile acids drive colonic secretion of glucagon-like-peptide 1 and peptide-YY in rodents. American Journal of Physiology: Gastrointestinal and Liver Physiology 2019316 G574-G584. (https://doi.org/10.1152/ ajpgi.00010.2019)

33 Kuhre RE, Wewer Albrechtsen NJ, Larsen O, Jepsen SL, Balk-Møller E, Andersen DB, Deacon CF, Schoonjans K, Reimann F, Gribble FM et al. Bile acids are important direct and indirect regulators of the secretion of appetite- and metabolism-regulating hormones from the gut and pancreas. Molecular Metabolism 201811 84-95. (https://doi. org/10.1016/j.molmet.2018.03.007)

34 Kumar DP, Rajagopal S, Mahavadi S, Mirshahi F, Grider JR, Murthy KS \& Sanyal AJ. Activation of transmembrane bile acid receptor TGR5 stimulates insulin secretion in pancreatic $\beta$ cells. Biochemical and Biophysical Research Communications 2012427 600-605. (https://doi. org/10.1016/j.bbrc.2012.09.104)

35 Kumar DP, Asgharpour A, Mirshahi F, Park SH, Liu S, Imai Y, Nadler JL, Grider JR, Murthy KS \& Sanyal AJ. Activation of transmembrane bile acid receptor tgr5 modulates pancreatic islet cells to promote glucose homeostasis. Journal of Biological Chemistry 2016291 6626-6640. (https://doi.org/10.1074/jbc.M115.699504)

36 Hirosumi J, Tuncman G, Chang L, Görgün CZ, Uysal KT, Maeda K, Karin M \& Hotamisligil GS. A central, role for JNK in obesity and insulin resistance. Nature 2002420 333-336. (https://doi org/10.1038/nature01137)

37 Hotamisligil GS, Shargill NS \& Spiegelman BM. Adipose expression of tumor necrosis factor- $\alpha$ : direct role in obesity-linked insulin resistance. Science 1993259 87-91. (https://doi.org/10.1126/ science.7678183)

38 Symonds ME, Aldiss P, Pope M \& Budge H. Recent advances in our understanding of brown and beige adipose tissue: the good fat that keeps you healthy [version 1; referees: 2 approved] [Internet]. F1000Research 20187 F1000Research. (https://doi.org/10.12688/ f1000research.14585.1)

39 Velazquez-Villegas LA, Perino A, Lemos V, Zietak M, Nomura M, Pols TWH \& Schoonjans K. TGR5 signalling promotes mitochondrial fission and beige remodelling of white adipose tissue. Nature Communications 20189 245. (https://doi.org/10.1038/s41467-01702068-0)

40 Zietak M \& Kozak LP. Bile acids induce uncoupling protein 1-dependent thermogenesis and stimulate energy expenditure at thermoneutrality in mice. American Journal of Physiology: Endocrinology and Metabolism 2016310 E346-E354. (https://doi. org/10.1152/ajpendo.00485.2015)

41 Huang S, Ma S, Ning M, Yang W, Ye Y, Zhang L, Shen J \& Leng Y. TGR5 agonist ameliorates insulin resistance in the skeletal muscles and improves glucose homeostasis in diabetic mice. Metabolism: Clinical and Experimental 201999 45-56. (https://doi.org/10.1016/j. metabol.2019.07.003)

42 Kobayashi Y, Hara N, Sugimoto R, Mifuji-Moroka R, Tanaka H, Eguchi A, Iwasa M, Hasegawa H, Iwata K, Takei Y et al. The associations between circulating bile acids and the muscle volume in patients with non-alcoholic fatty liver disease (NAFLD). Internal Medicine 201756 755-762. (https://doi.org/10.2169/internalmedicine.56.7796)

43 Ichikawa R, Takayama T, Yoneno K, Kamada N, Kitazume MT, Higuchi H, Matsuoka K, Watanabe M, Itoh H, Kanai T et al. Bile acids induce monocyte differentiation toward interleukin-12 hypo-producing dendritic cells via a TGR5-dependent pathway. Immunology 2012136 153-162. (https://doi.org/10.1111/j.13652567.2012.03554.x) 
44 Yoneno K, Hisamatsu T, Shimamura K, Kamada N, Ichikawa R, Kitazume MT, Mori M, Uo M, Namikawa Y, Matsuoka K et al. TGR5 signalling inhibits the production of pro-inflammatory cytokines by in vitro differentiated inflammatory and intestinal macrophages in Crohn's disease. Immunology 2013139 19-29. (https://doi. org/10.1111/imm.12045)

45 Juřica J, Dovrtělová G, Nosková K \& Zendulka O. Bile acids, nuclear receptors and cytochrome P450. Physiological Research $2016 \mathbf{6 5}$ S427-S440. (https://doi.org/10.33549/physiolres.933512)

46 Zhou J, Zhai Y, Mu Y, Gong H, Uppal H, Toma D, Ren S, Evans RM \& $\mathrm{Xie} W$. A novel pregnane $\mathrm{X}$ receptor-mediated and sterol regulatory element-binding protein-independent lipogenic pathway. Journal of Biological Chemistry 2006281 15013-15020. (https://doi. org/10.1074/jbc.M511116200)

47 Hakkola J, Rysä J \& Hukkanen J. Regulation of hepatic energy metabolism by the nuclear receptor PXR. BBA: Gene Regulatory Mechanisms 20161859 1072-1082. (https://doi.org/10.1016/j. bbagrm.2016.03.012)

48 Sultana H, Watanabe K, Rana MM, Takashima R, Ohashi A, Komai M $\&$ Shirakawa H. Effects of vitamin $\mathrm{K} 2$ on the expression of genes involved in bile acid synthesis and glucose homeostasis in mice with humanized PXR. Nutrients 201810 982. (https://doi.org/10.3390/ nu10080982)

49 Ishizawa M, Akagi D \& Makishima M. Lithocholic acid is a vitamin $\mathrm{D}$ receptor ligand that acts preferentially in the ileum. International Journal of Molecular Sciences 201819 1975. (https://doi.org/10.3390/ ijms19071975)

50 Yao B, He J, Yin X, Shi Y, Wan J \& Tian Z. The protective effect of lithocholic acid on the intestinal epithelial barrier is mediated by the vitamin D receptor via a SIRT1/Nrf2 and NF- $\mathrm{BB}$ dependent mechanism in Caco-2 cells. Toxicology Letters 2019316 109-118. (https://doi.org/10.1016/j.toxlet.2019.08.024)

51 Neelankal John A, Iqbal Z, Colley S, Morahan G, Makishima M $\&$ Jiang FX. Vitamin D receptor-targeted treatment to prevent pathological dedifferentiation of pancreatic $\beta$ cells under hyperglycaemic stress. Diabetes and Metabolism 201844 269-280. (https://doi.org/10.1016/j.diabet.2017.07.006)

52 De Marino S, Carino A, Masullo D, Finamore C, Marchianò S, Cipriani S, Di Leva FS, Catalanotti B, Novellino E, Limongelli V et al. Hyodeoxycholic acid derivatives as liver X receptor $\alpha$ and G-proteincoupled bile acid receptor agonists. Scientific Reports 2017 7 1-13. (https://doi.org/10.1038/srep43290)

53 Song C, Hiipakka RA \& Liao S. Selective activation of liver X receptor alpha by $6 \alpha$-hydroxy bile acids and analogs. Steroids $2000 \mathbf{6 5}$ 423-427. (https://doi.org/10.1016/s0039-128x(00)00127-6)

54 Gautam D, Han SJ, Hamdan FF, Jeon J, Li B, Li JH, Cui Y, Mears D, $\mathrm{Lu} \mathrm{H}$, Deng C et al. A critical role for $\beta$ cell M3 muscarinic acetylcholine receptors in regulating insulin release and blood glucose homeostasis in vivo. Cell Metabolism 20063 449-461. (https://doi.org/10.1016/j.cmet.2006.04.009)

55 Zhu L, Rossi M, Cohen A, Pham J, Zheng H, Dattaroy D, Mukaibo T, Melvin JE, Langel JL, Hattar S et al. Allosteric modulation of $\beta$-cell M3 muscarinic acetylcholine receptors greatly improves glucose homeostasis in lean and obese mice. PNAS 2019116 18684-18690. (https://doi.org/10.1073/pnas.1904943116)

56 Adada M, Canals D, Hannun YA \& Obeid LM. Sphingosine-1phosphate receptor 2. FEBS Journal 2013280 6354-6366. (https:// doi.org/10.1111/febs.12446)

57 Nagahashi M, Takabe K, Liu R, Peng K, Wang X, Wang Y, Hait NC, Wang X, Allegood JC, Yamada A et al. Conjugated bile acid-activated $\mathrm{S} 1 \mathrm{P}$ receptor 2 is a key regulator of sphingosine kinase 2 and hepatic gene expression. Hepatology 201561 1216-1226. (https://doi. org/10.1002/hep.27592)

58 Dai Y, Liu J, Yuan E, Li Y, Wang Q, Jia L, Wang L \& Su Y. Gestational age-specific reference intervals for 15 biochemical measurands during normal pregnancy in China. Annals of Clinical Biochemistry $2018 \mathbf{5 5}$ 446-452. (https://doi.org/10.1177/0004563217738801)

59 Zhu B, Yin P, Ma Z, Ma Y, Zhang H, Kong H \& Zhu Y. Characteristics of bile acids metabolism profile in the second and third trimesters of normal pregnancy. Metabolism: Clinical and Experimental 201995 77-83. (https://doi.org/10.1016/j.metabol.2019.04.004)

60 Larsson A, Palm M, Hansson LO \& Axelsson O. Reference values for clinical chemistry tests during normal pregnancy. BJOG $2008 \mathbf{1 1 5}$ 874-881. (https://doi.org/10.1111/j.1471-0528.2008.01709.x)

61 Fulton IC, Douglas JG, Hutchon DJR \& Beckett GJ. Is normal pregnancy cholestatic? Clinica Chimica Acta: International Journal of Clinical Chemistry 1983130 171-176. (https://doi.org/10.1016/00098981(83)90114-6)

62 Carter J. Serum bile acids in normal pregnancy. British Journal of Obstetrics and Gynaecology 199198 540-543. (https://doi. org/10.1111/j.1471-0528.1991.tb10367.x)

63 Collado MC, Isolauri E, Laitinen K \& Salminen S. Distinct composition of gut microbiota during pregnancy in overweight and normal-weight women. American Journal of Clinical Nutrition $2008 \mathbf{8 8}$ 894-899. (https://doi.org/10.1093/ajcn/88.4.894)

64 Koren O, Goodrich JK, Cullender TC, Spor A, Laitinen K, Bäckhed HK, Gonzalez A, Werner JJ, Angenent LT, Knight R et al. Host remodeling of the gut microbiome and metabolic changes during pregnancy. Cell 2012150 470-480. (https://doi.org/10.1016/j.cell.2012.07.008)

65 Ovadia C, Perdones-Montero A, Spagou K, Smith A, Sarafian MH, Gomez-Romero M, Bellafante E, Clarke LCD, Sadiq F, Nikolova V et al. Enhanced microbial bile acid deconjugation and impaired ileal uptake in pregnancy repress intestinal regulation of bile acid synthesis. Hepatology 201970 276-293. (https://doi.org/10.1002/ hep.30661)

66 Moscovitz JE, Kong B, Buckley K, Buckley B, Guo GL \& Aleksunes LM. Restoration of enterohepatic bile acid pathways in pregnant mice following short term activation of Fxr by GW4064 Toxicology and Applied Pharmacology 2016310 60-67. (https://doi. org/10.1016/j.taap.2016.08.021)

67 Milona A, Owen BM, Cobbold JFL, Willemsen ECL, Cox IJ, Boudjelal M, Cairns W, Schoonjans K, Taylor-Robinson SD, Klomp LW et al. Raised hepatic bile acid concentrations during pregnancy in mice are associated with reduced farnesoid $\mathrm{X}$ receptor function. Hepatology 201052 1341-1349. (https://doi.org/10.1002/ hep.23849)

68 Aleksunes LM, Yeager RL, Wen X, Cui JY \& Klaassen CD. Repression of hepatobiliary transporters and differential regulation of classic and alternative bile acid pathways in mice during pregnancy. Toxicological Sciences 2012130 257-268. (https://doi.org/10.1093/toxsci/kfs248)

69 Chen Y, Vasilenko A, Song X, Valanejad L, Verma R, You S, Yan B, Shiffka S, Hargreaves L, Nadolny C et al. Estrogen and estrogen receptor- $\alpha$-mediated transrepression of bile salt export pump. Molecular Endocrinology 201529 613-626. (https://doi.org/10.1210/ me.2015-1014)

70 Parini P, Angelin B, Stavréus-Evers A, Freyschuss B, Eriksson H \& Rudling M. Biphasic effects of the natural estrogen $17 \beta$-estradiol on hepatic cholesterol metabolism in intact female rats. Arteriosclerosis, Thrombosis, and Vascular Biology 200020 1817-1823. (https://doi. org/10.1161/01.atv.20.7.1817)

71 Abu-Hayyeh S, Papacleovoulou G, Lövgren-Sandblom A, Tahir M, Oduwole O, Jamaludin NA, Ravat S, Nikolova V, Chambers J, Selden C et al. Intrahepatic cholestasis of pregnancy levels of sulfated progesterone metabolites inhibit farnesoid $X$ receptor resulting in a cholestatic phenotype. Hepatology 201357 716-726. (https://doi. org/10.1002/hep.26055)

72 Abu-Hayyeh S, Martinez-Becerra P, Abdul Kadir SHS, Selden C, Romero MR, Rees M, Marschall HU, Marin JJ \& Williamson C. Inhibition of $\mathrm{Na}$--taurocholate co-transporting polypeptide-mediated bile acid transport by cholestatic sulfated progesterone metabolites. 
Journal of Biological Chemistry 2010285 16504-16512. (https://doi. org/10.1074/jbc.M109.072140)

73 Vallejo M, Briz O, Serrano MA, Monte MJ \& Marin JJG. Potential role of trans-inhibition of the bile salt export pump by progesterone metabolites in the etiopathogenesis of intrahepatic cholestasis of pregnancy. Journal of Hepatology 200644 1150-1157. (https://doi. org/10.1016/j.jhep.2005.09.017)

74 Zheng W, Huang W, Zhang L, Tian Z, Wang T, Zhang T, Zhang Z, Zhang W \& Li G. Changes in serum lipid levels during pregnancy and association with neonatal outcomes: a large cohort study. Reproductive Sciences 201825 1406-1412. (https://doi. org/10.1177/1933719117746785)

75 Dathan-Stumpf A, Vogel M, Jank A, Thiery J, Kiess W \& Stepan H. Reference intervals of serum lipids in the second and third trimesters of pregnancy in a Caucasian cohort: the LIFE Child study. Archives of Gynecology and Obstetrics 2019300 1531-1539. (https://doi. org/10.1007/s00404-019-05342-2)

76 Zeng Z, Liu F \& Li S. Metabolic adaptations in pregnancy: a review. Annals of Nutrition and Metabolism 201770 59-65. (https://doi. org $/ 10.1159 / 000459633)$

77 Hill D \& Szlapinski SK. Metabolic adaptations to pregnancy in healthy and gestational diabetic pregnancies: the pancreas - placenta axis. Current Vascular Pharmacology 2020 18. (https://doi.org/10.2174 /1570161118666200320111209)

78 Nadal A, Alonso-Magdalena P, Soriano S, Ropero AB \& Quesada I. The role of oestrogens in the adaptation of islets to insulin resistance. Journal of Physiology 2009587 5031-5037. (https://doi.org/10.1113/ jphysiol.2009.177188)

79 Masuyama H \& Hiramatsu Y. Potential role of estradiol and progesterone in insulin resistance through constitutive androstane receptor. Journal of Molecular Endocrinology 201147 229-239. (https:// doi.org/10.1530/JME-11-0046)

80 Root-Bernstein R, Podufaly A \& Dillon PF. Estradiol binds to insulin and insulin receptor decreasing insulin binding in vitro. Frontiers in Endocrinology 20145 118. (https://doi.org/10.3389/fendo.2014.00118)

81 Wada T, Hori S, Sugiyama M, Fujisawa E, Nakano T, Tsuneki H, Nagira K, Saito S \& Sasaoka T. Progesterone inhibits glucose uptake by affecting diverse steps of insulin signaling in 3T3-L1 adipocytes. American Journal of Physiology: Endocrinology and Metabolism 2010298 E881-E888. (https://doi.org/10.1152/ajpendo.00649.2009)

82 Valsamakis G, Margeli A, Vitoratos N, Boutsiadis A, Sakkas EG, Papadimitriou G, Al-Daghri NM, Botsis D, Kumar S, Papassotiriou I et al. The role of maternal gut hormones in normal pregnancy: fasting plasma active glucagon-like peptide 1 level is a negative predictor of fetal abdomen circumference and maternal weight change. European Journal of Endocrinology 2010162 897-903. ((https://doi.org/10.1530/EJE-10-0047)

83 Moffett RC, Vasu S, Thorens B, Drucker DJ \& Flatt PR. Incretin receptor null mice reveal key role of GLP-1 but not GIP in pancreatic beta cell adaptation to pregnancy. PLoS ONE 20149 e96863. (https:// doi.org/10.1371/journal.pone.0096863)

84 Glantz A, Marschall HU \& Mattsson LA. Intrahepatic cholestasis of pregnancy: relationships between bile acid levels and fetal complication rates. Hepatology $2004 \mathbf{4 0} 467-474$. (https://doi. org/10.1002/hep.20336)

85 Geenes V, Chappell LC, Seed PT, Steer PJ, Knight M \& Williamson C. Association of severe intrahepatic cholestasis of pregnancy with adverse pregnancy outcomes: a prospective population-based case-control study. Hepatology 201459 1482-1491. (https://doi. org/10.1002/hep.26617)

86 Ovadia C, Seed PT, Sklavounos A, Geenes V, Di Illio C, Chambers J, Kohari K, Bacq Y, Bozkurt N, Brun-Furrer R et al. Association of adverse perinatal outcomes of intrahepatic cholestasis of pregnancy with biochemical markers: results of aggregate and individual patient data meta-analyses. Lancet 2019393 899-909. (https://doi. org/10.1016/S0140-6736(18)31877-4)
87 Abu-Hayyeh S, Ovadia C, Lieu T, Jensen DD, Chambers J, Dixon PH, Lövgren-Sandblom A, Bolier R, Tolenaars D, Kremer AE et al. Prognostic and mechanistic potential of progesterone sulfates in intrahepatic cholestasis of pregnancy and pruritus gravidarum. Hepatology 201663 1287-1298. (https://doi.org/10.1002/ hep.28265)

88 Turro E, Astle WJ, Megy K, Gräf S, Greene D, Shamardina O, Allen HL, Sanchis-Juan A, Frontini M, Thys C et al. Whole-genome sequencing of patients with rare diseases in a national health system. Nature 2020583 96-102. (https://doi.org/10.1038/s41586-020-24342)

89 Dixon PH, Sambrotta M, Chambers J, Taylor-Harris P, Syngelaki A, Nicolaides K, Knisely AS, Thompson RJ \& Williamson C. An expanded role for heterozygous mutations of ABCB4, ABCB11, ATP8B1, ABCC2 and TJP2 in intrahepatic cholestasis of pregnancy [Internet]. Scientific Reports 20177 11823. (https://doi.org/10.1038/ s41598-017-11626-x)

90 Brites D, Rodrigues CMP, Van-Zeller H, Brito A \& Silva R. Relevance of serum bile acid profile in the diagnosis of intrahepatic cholestasis of pregnancy in an high incidence area: Portugal. European Journal of Obstetrics, Gynecology, and Reproductive Biology 199880 31-38. (https://doi.org/10.1016/s0301-2115(98)00086-4)

91 Heikkinen J. Serum bile acids in the early diagnosis of intrahepatic cholestasis of pregnancy. Obstetrics and Gynecology 198361 581-587.

92 Pavlović N, Goločorbin-Kon S, Danić M, Stanimirov B, Al-Salami H, Stankov K \& Mikov M. Bile acids and their derivatives as potential modifiers of drug release and pharmacokinetic profiles. Frontiers in Pharmacology 20189 1283. (https://doi.org/10.3389/ fphar.2018.01283)

93 Alemi F, Kwon E, Poole DP, Lieu TM, Lyo V, Cattaruzza F, Cevikbas F, Steinhoff M, Nassini R, Materazzi S et al. The TGR5 receptor mediates bile acid-induced itch and analgesia. Journal of Clinical Investigation 2013123 1513-1530. (https://doi.org/10.1172/JCI64551)

94 Lieu T, Jayaweera G, Zhao P, Poole DP, Jensen D, Grace M, McIntyre P, Bron R, Wilson YM, Krappitz M et al. The bile acid receptor TGR5 activates the trpa1 channel to induce itch in mice. Gastroenterology 2014147 1417-1428. (https://doi.org/10.1053/j. gastro.2014.08.042)

95 Williamson C, Gorelik J, Eaton BM, Lab M, Swiet M de \& Korchev Y. The bile acid taurocholate impairs rat cardiomyocyte function: a proposed mechanism for intra-uterine fetal death in obstetric cholestasis. Clinical Science 2001100 363-369. (https://doi. org/10.1042/cs1000363)

96 Sheikh Abdul Kadir SH, Miragoli M, Abu-Hayyeh S, Moshkov AV, Xie Q, Keitel V et al. Bile acid-induced arrhythmia is mediated by muscarinic M2 receptors in neonatal rat cardiomyocytes. PLOS ONE 20105 e9689. (https://doi.org/10.1371/journal.pone.0009689)

97 Rodríguez M, Moreno J, Márquez R, Eltit R, Martinez F, SepúlvedaMartínez A \& Parra-Cordero M. Increased PR interval in fetuses of patients with intrahepatic cholestasis of pregnancy. Fetal Diagnosis and Therapy 201640 298-302. (https://doi.org/10.1159/000444297)

98 Vasavan T, Deepak S, Jayawardane IA, Lucchini M, Martin C, Geenes V, Yang J, Lövgren-Sandblom A, Seed PT, Chambers J et al. Fetal cardiac dysfunction in intrahepatic cholestasis of pregnancy is associated with elevated serum bile acid concentrations. Journal of Hepatology 2020 In press. (https://doi.org/10.1016/j.jhep.2020.11.038)

99 Marschall HU, Wagner M, Zollner G, Fickert P, Diczfalusy U, Gumhold J, Silbert D, Fuchsbichler A, Benthin L, Grundström R et al. Complementary stimulation of hepatobiliary transport and detoxification systems by rifampicin and ursodeoxycholic acid in humans. Gastroenterology 2005129 476-485. (https://doi. org/10.1016/j.gastro.2005.05.009)

100 Beuers U. Drug insight: mechanisms and sites of action of ursodeoxycholic acid in cholestasis [Internet]. Nature Clinical Practice: Gastroenterology and Hepatology 20063 318-328. (https://doi. org/10.1038/ncpgasthep0521) 
101 Beuers U, Trauner M, Jansen P \& Poupon R. New paradigms in the treatment of hepatic cholestasis: from UDCA to FXR, PXR and beyond [Internet]. Journal of Hepatology 201562 (Supplement) S25-S37. (https://doi.org/10.1016/j.jhep.2015.02.023)

102 Manna LB, Ovadia C, Lövgren-Sandblom A, Chambers J, Begum S, Seed P, Walker I, Chappell LC, Marschall H-U \& Williamson C. Enzymatic quantification of total serum bile acids as a monitoring strategy for women with intrahepatic cholestasis of pregnancy receiving ursodeoxycholic acid treatment: a cohort study. BJOG 2019 126 1633-1640. (https://doi.org/10.1111/1471-0528.15926)

103 Bacq Y, le Besco M, Lecuyer AI, Gendrot C, Potin J, Andres CR \& Aubourg A. Ursodeoxycholic acid therapy in intrahepatic cholestasis of pregnancy: results in real-world conditions and factors predictive of response to treatment. Digestive and Liver Disease 201749 63-69. (https://doi.org/10.1016/j.dld.2016.10.006)

104 Kong X, Kong Y, Zhang F, Wang T \& Yan J. Evaluating the effectiveness and safety of ursodeoxycholic acid in treatment of intrahepatic cholestasis of pregnancy: a meta-analysis (a prismacompliant study). Medicine 201695 e4949. (https://doi.org/10.1097/ MD.0000000000004949)

105 Chappell LC, Bell JL, Smith A, Linsell L, Juszczak E, Dixon PH, Chambers J, Hunter R, Dorling J, Williamson C et al. Ursodeoxycholic acid versus placebo in women with intrahepatic cholestasis of pregnancy (PITCHES): a randomised controlled trial. Lancet 2019394 849-860. (https://doi.org/10.1016/S01406736(19)31270-X)

106 McIntyre HD, Catalano P, Zhang C, Desoye G, Mathiesen ER \& Damm P. Gestational diabetes mellitus. Nature Reviews: Disease Primers 20195 47. (https://doi.org/10.1038/s41572-019-0098-8)

107 HAPO Study Cooperative Research Group, Metzger BE, Lowe LP, Dyer AR, Trimble ER, Chaovarindr U, Coustan DR, Hadden DR, McCance DR, Hod M et al. Hyperglycemia and adverse pregnancy outcomes. New England Journal of Medicine 2008358 1991-2002. (https://doi.org/10.1056/NEJMoa0707943)

108 O'Sullivan EP, Avalos G, O'Reilly M, Dennedy MC, Gaffney G, Dunne F \& Atlantic DIP collaborators. Atlantic Diabetes in Pregnancy (DIP): the prevalence and outcomes of gestational diabetes mellitus using new diagnostic criteria. Diabetologia 201154 1670-1675. (https://doi.org/10.1007/s00125-011-2150-4)

109 Athukorala C, Crowther CA, Willson K, Hiller JE, Moss JR, McPhee AJ \& Australian Carbohydrate Intolerance Study in Pregnant Women (ACHOIS) Trial Group. Women with gestational diabetes mellitus in the ACHOIS trial: risk factors for shoulder dystocia. Australian and New Zealand Journal of Obstetrics and Gynaecology 200747 37-41. (https://doi.org/10.1111/j.1479-828X.2006.00676.x)

110 Lowe WL, Scholtens DM, Lowe LP, Kuang A, Nodzenski M, Talbot O, Catalano PM, Linder B, Brickman WJ, Clayton P et al. Association of gestational diabetes with maternal disorders of glucose metabolism and childhood adiposity. JAMA 2018320 1005-1016. (https://doi. org/10.1001/jama.2018.11628)

111 Leybovitz-Haleluya N, Wainstock T, Landau D \& Sheiner E. Maternal gestational diabetes mellitus and the risk of subsequent pediatric cardiovascular diseases of the offspring: a population-based cohort study with up to 18 years of follow up. Acta Diabetologica $2018 \mathbf{5 5}$ 1037-1042. (https://doi.org/10.1007/s00592-018-1176-1)

112 Kawasaki M, Arata N, Miyazaki C, Mori R, Kikuchi T, Ogawa Y \& Ota E. Obesity and abnormal glucose tolerance in offspring of diabetic mothers: a systematic review and meta-analysis [Internet]. PLoS ONE 201813 e0190676. (https://doi.org/10.1371/journal.pone.0190676)

113 Blotsky AL, Rahme E, Dahhou M, Nakhla M \& Dasgupta K. Gestational diabetes associated with incident diabetes in childhood and youth: a retrospective cohort study. Canadian Medical Association Journal 2019191 E410-E417. (https://doi.org/10.1503/cmaj.181001)

114 American Diabetes Association. Management of diabetes in pregnancy: standards of medical care in diabetes 2019. Diabetes Care 201942 (Supplement 1) S165-S172. (https://doi.org/10.2337/dc19-S014)
115 Rowan JA, Hague WM, Gao W, Battin MR, Moore MP \& MiG Trial Investigators. Metformin versus insulin for the treatment of gestational diabetes. New England Journal of Medicine $2008 \mathbf{3 5 8}$ 2003-2015. (https://doi.org/10.1056/NEJMoa0707193)

116 Rowan JA, Rush EC, Obolonkin V, Battin M, Wouldes T \& Hague WM. Metformin in gestational diabetes: the offspring follow-up (MiG TOFU) - body composition at 2 years of age. Diabetes Care 201134 2279-2284. (https://doi.org/10.2337/dc11-0660)

117 Hanem LGE, Salvesen Ø, Juliusson PB, Carlsen SM, Nossum MCF, Vaage MØ, Ødegård R \& Vanky E. Intrauterine metformin exposure and offspring cardiometabolic risk factors (PedMet study): a 5-10 year follow-up of the PregMet randomised controlled trial. Lancet: Child and Adolescent Health 20193 166-174. (https://doi.org/10.1016/ S2352-4642(18)30385-7)

118 Barbour LA, Scifres C, Valent AM, Friedman JE, Buchanan TA, Coustan D, Aagaard K, Thornburg KL, Catalano PM, Galan HL et al. A cautionary response to SMFM statement: pharmacological treatment of gestational diabetes. American Journal of Obstetrics and Gynecology 2018219 367.e1-367.e7. (https://doi.org/10.1016/j. ajog.2018.06.013)

119 Panagiotopoulou O, Syngelaki A, Georgiopoulos G, Simpson J, Akolekar R, Shehata H, Nicolaides K \& Charakida M. Metformin use in obese mothers is associated with improved cardiovascular profile in the offspring. American Journal of Obstetrics and Gynecology 2020 223 246.e1-246.e10. (https://doi.org/10.1016/j.ajog.2020.01.054)

120 Martis R, Crowther CA, Shepherd E, Alsweiler J, Downie MR \& Brown J. Treatments for women with gestational diabetes mellitus: an overview of Cochrane systematic reviews [Internet]. Cochrane Database of Systematic Reviews $2018 \mathbf{8}$ CD012327. (https://doi. org/10.1002/14651858.CD012327.pub2)

121 Langer O, Conway DL, Berkus MD, Xenakis EMJ \& Gonzales O. A comparison of glyburide and insulin in women with gestational diabetes mellitus. New England Journal of Medicine 2000343 1134-1138. (https://doi.org/10.1056/NEJM200010193431601)

122 Reynolds RM, Denison FC, Juszczak E, Bell JL, Penneycard J, Strachan MWJ, Lindsay RS, Alexander CI, Love CDB, Whyte S et al. Glibenclamide and metfoRmin versus stAndard care in gEstational diabeteS (GRACES): a feasibility open label randomised trial. BMC Pregnancy and Childbirth 201717 316. (https://doi.org/10.1186/ s12884-017-1505-3)

123 Balsells M, García-Patterson A, Solà I, Roqué M, Gich I \& Corcoy R. Glibenclamide, metformin, and insulin for the treatment of gestational diabetes: a systematic review and meta-analysis. BMJ 2015 350 h102. (https://doi.org/10.1136/bmj.h102)

124 Landon MB, Rice MM, Varner MW, Casey BM, Reddy UM, Wapner RJ, Rouse DJ, Biggio Jr JR, Thorp JM, Chien EK et al. Mild gestational diabetes mellitus and long-term child health. Diabetes Care 201538 445-452. (https://doi.org/10.2337/dc14-2159)

125 Shou C, Wei Y-M, Wang C \& Yang H-X. Updates in long-term maternal and fetal adverse effects of gestational diabetes mellitus. Maternal-Fetal Medicine 20191 91-94. (https://doi.org/10.1097/ FM9.0000000000000019)

126 Zaborska KE \& Cummings BP. Rethinking bile acid metabolism and signaling for Type 2 diabetes treatment [Internet]. Current Diabetes Reports 201818 109. (https://doi.org/10.1007/s11892-0181092-3)

127 Kaur A, Patankar JV, De Haan W, Ruddle P, Wijesekara N, Groen AK, Verchere CB, Singaraja RR \& Hayden MR. Loss of Cyp8b1 improves glucose homeostasis by increasing GLP-1. Diabetes 201564 1168-1179. https://doi.org/10.2337/db14-0716)

128 Majewska A, Godek B, Bomba-Opon D \& Wielgos M. Association between intrahepatic cholestasis in pregnancy and gestational diabetes mellitus. A retrospective analysis. Ginekologia Polska 201990 458-463. (https://doi.org/10.5603/GP.2019.0079)

129 Arafa A \& Dong JY. Association between intrahepatic cholestasis of pregnancy and risk of gestational diabetes and preeclampsia: a 
systematic review and meta-analysis. Hypertension in Pregnancy 2020 39 354-360. (https://doi.org/10.1080/10641955.2020.1758939)

130 Gao J, Xu B, Zhang X, Cui Y, Deng L, Shi Z, Shao Y \& Ding M. Association between serum bile acid profiles and gestational diabetes mellitus: a targeted metabolomics study. Clinica Chimica Acta: International Journal of Clinical Chemistry 2016459 63-72. (https:// doi.org/10.1016/j.cca.2016.05.026)

131 Hou W, Meng X, Zhao W, Pan J, Tang J, Huang Y, Tao M, Liu F \& Jia W. Elevated first-trimester total bile acid is associated with the risk of subsequent gestational diabetes. Scientific Reports 20166 1-8. (https://doi.org/10.1038/srep34070)

132 Hou W, Meng X, Zhao A, Zhao W, Pan J, Tang J, Huang Y, Li H, Jia W, Liu F et al. Development of multimarker diagnostic models from metabolomics analysis for gestational diabetes mellitus (GDM). Molecular and Cellular Proteomics 201817 431-441. (https://doi. org/10.1074/mcp.RA117.000121)

133 Dudzik D, Zorawski M, Skotnicki M, Zarzycki W, Kozlowska G, Bibik-Malinowska K, Vallejo M, García A, Barbas C \& Ramos MP. Metabolic fingerprint of gestational diabetes mellitus. Journal of Proteomics 2014103 57-71. (https://doi.org/10.1016/j. jprot.2014.03.025)

134 Li J, Huo X, Cao YF, Li SN, Du Z, Shao P, Leng J, Zhang C, Sun XY, Ma RCW et al. Bile acid metabolites in early pregnancy and risk of gestational diabetes in Chinese women: a nested case-control study. EBiomedicine 201835 317-324. (https://doi.org/10.1016/j. ebiom.2018.08.015)

135 Bellafante E, McIlvride S, Nikolova V, Fan HM, Manna LB, Chambers J, Machirori M, Banerjee A, Murphy K, Martineau M et al. Maternal glucose homeostasis is impaired in mouse models of gestational cholestasis. Scientific Reports 202010 11523. (https://doi. org/10.1038/s41598-020-67968-6)

136 Mudaliar S, Henry RR, Sanyal AJ, Morrow L, Marschall HU, Kipnes M, Adorini L, Sciacca CI, Clopton P, Castelloe E et al. Efficacy and safety of the farnesoid $\mathrm{X}$ receptor agonist obeticholic acid in patients with type 2 diabetes and nonalcoholic fatty liver disease. Gastroenterology 2013145 574.e1-82.e1. (https://doi.org/10.1053/j. gastro.2013.05.042)

137 McIlvride S, Nikolova V, Fan HM, McDonald JAK, Wahlström A, Bellafante E, Jansen E, Adorini L, Shapiro D, Jones P et al. Obeticholic acid ameliorates dyslipidemia but not glucose tolerance in mouse model of gestational diabetes. American Journal of Physiology: Endocrinology and Metabolism 2019317 E399-E410. (https://doi. org/10.1152/ajpendo.00407.2018)

138 Wu WB, Xu YY, Cheng WW, Wang YX, Liu Y, Huang D \& Zhang HJ. Agonist of farnesoid $X$ receptor protects against bile acid induced damage and oxidative stress in mouse placenta - a study on maternal cholestasis model. Placenta 201536 545-551. (https://doi. org/10.1016/j.placenta.2015.02.005)

139 Pataia V, McIlvride S, Papacleovoulou G, Ovadia C, McDonald JAK, Wahlström A, Jansen E, Adorini L, Shapiro D, Marchesi JR et al. Obeticholic acid improves fetal bile acid profile in a mouse model of gestational hypercholanemia. American Journal of Physiology: Gastrointestinal and Liver Physiology 2020319 G197-G211. (https:// doi.org/10.1152/ajpgi.00126.2020)

140 Rizzo G, Passeri D, De Franco F, Ciaccioli G, Donadio L, Rizzo G, Orlandi S, Sadeghpour B, Wang XX, Jiang T et al. Functional characterization of the semisynthetic bile acid derivative INT-767, a dual farnesoid X receptor and TGR5 agonist. Molecular Pharmacology 201078 617-630. (https://doi.org/10.1124/mol.110.064501)

141 Zambad SP, Tuli D, Mathur A, Ghalsasi SA, Chaudhary AR, Deshpande S, Gupta RC, Chauthaiwale V \& Dutt C. TRC210258, a novel TGR5 agonist, reduces glycemic and dyslipidemic cardiovascular risk in animal models of diabesity. Diabetes, Metabolic Syndrome and Obesity: Targets and Therapy 20137 1-14. (https://doi. org/10.2147/DMSO.S50209)

142 Phillips DP, Gao W, Yang Y, Zhang G, Lerario IK, Lau TL, Jiang J, Wang X, Nguyen DG, Bhat BG et al. Discovery of trifluoromethyl(pyrimidin-2-yl)azetidine-2-carboxamides as potent, orally bioavailable TGR5 (GPBAR1) agonists: structure-activity relationships, lead optimization, and chronic in vivo efficacy. Journal of Medicinal Chemistry 201457 3263-3282. (https://doi.org/10.1021/ jm401731q)

143 Zheng C, Zhou W, Wang T, You P, Zhao Y, Yang Y, Wang X, Luo J, Chen Y, Liu M et al. A novel TGR5 activator WB403 promotes GLP-1 secretion and preserves pancreatic $\beta$-cells in type 2 diabetic mice. PLoS ONE 201510 e0134051. (https://doi.org/10.1371/journal. pone.0134051)

144 Agarwal S, Sasane S, Kumar J, Deshmukh P, Bhayani H, Giri P, Giri S, Soman S, Kulkarni N \& Jain M. Evaluation of novel TGR5 agonist in combination with sitagliptin for possible treatment of type 2 diabetes. Bioorganic and Medicinal Chemistry Letters 201828 1849-1852. (https://doi.org/10.1016/j.bmcl.2018.04.011)

145 Finn PD, Rodriguez D, Kohler J, Jiang Z, Wan S, Blanco E, King AJ, Chen T, Bell N, Dragoli D et al. Intestinal TGR5 agonism improves hepatic steatosis and insulin sensitivity in western diet-fed mice. American Journal of Physiology: Gastrointestinal and Liver Physiology 2019316 G412-G424. (https://doi.org/10.1152/ ajpgi.00300.2018)

146 Hodge RJ, Lin J, Vasist Johnson LS, Gould EP, Bowers GD, Nunez DJ \& SB-756050 Project Team. Safety, pharmacokinetics, and pharmacodynamic effects of a selective TGR5 agonist, SB-756050, in Type 2 diabetes. Clinical Pharmacology in Drug Development 20132 213-222. (https://doi.org/10.1002/cpdd.34)

147 Lasalle M, Hoguet V, Hennuyer N, Leroux F, Piveteau C, Belloy L, Lestavel S, Vallez E, Dorchies E, Duplan I et al. Topical intestinal aminoimidazole agonists of G-protein-coupled bile acid receptor 1 promote glucagon like peptide- 1 secretion and improve glucose tolerance. Journal of Medicinal Chemistry 201760 4185-4211. (https:// doi.org/10.1021/acs.jmedchem.6b01873)

148 Chen T, Reich NW, Bell N, Finn PD, Rodriguez D, Kohler J, Kozuka K, He L, Spencer AG, Charmot D et al. Design of gut-restricted thiazolidine agonists of $\mathrm{G}$ protein-coupled bile acid receptor 1 (GPBAR1, TGR5). Journal of Medicinal Chemistry 201861 7589-7613. (https://doi.org/10.1021/acs.jmedchem.8b00308)

149 Shima KR, Ota T, Kato KI, Takeshita Y, Misu H, Kaneko S \& Takamura T. Ursodeoxycholic acid potentiates dipeptidyl peptidase- 4 inhibitor sitagliptin by enhancing glucagon-like peptide- 1 secretion in patients with type 2 diabetes and chronic liver disease: a pilot randomized controlled and add-on study. BMJ Open Diabetes Research and Care 20186 e000469. (https://doi.org/10.1136/ bmjdrc-2017-000469)

150 Sánchez-García A, Sahebkar A, Simental-Mendía M \& SimentalMendía LE. Effect of ursodeoxycholic acid on glycemic markers: a systematic review and meta-analysis of clinical trials [Internet]. Pharmacological Research 2018135 144-149. (https://doi. org/10.1016/j.phrs.2018.08.008)

151 Foghsgaard S, Andreasen C, Vedtofte L, Andersen ES, Bahne E, Strandberg C, Buhl T, Holst JJ, Svare JA, Clausen TD et al. Nonalcoholic fatty liver disease is prevalent in women with prior gestational diabetes mellitus and independently associated with insulin resistance and waist circumference. Diabetes Care $2017 \mathbf{4 0}$ 109-116. (https://doi.org/10.2337/dc16-1017) 